\title{
Firm Characteristics and Export Intensity in Kenyan Manufacturing Firms: An Empirical Analysis
}

\author{
Kipkurui Josphat Kipsaat \\ School of Economics, University of Nairobi, Nairobi, Kenya
}

Email address:

josphat.jk@gmail.com

To cite this article:

Kipkurui Josphat Kipsaat. Firm Characteristics and Export Intensity in Kenyan Manufacturing Firms: An Empirical Analysis. Journal of Business and Economic Development. Vol. 4, No. 1, 2019, pp. 31-37. doi: 10.11648/j.jbed.20190401.15

Received: February 21, 2019; Accepted: April 8, 2019; Published: May 20, 2019

\begin{abstract}
This paper examines the determinants of export intensity in Kenyan manufacturing firms. We use data from the World Bank enterprise survey 2013 and from it examine how firm characteristics explain export intensity. We use the Ordinary Least Squares estimation technique and Heckman sample selection model to estimate this relationship. The Heckman model is estimated in order to control for possible Sample Selection bias as export intensity is only observable in firms that make the decision to export. The findings show that innovation and certification are major determinants to export intensity as a unit change in these variables would result to a change in export intensity by 0.4747 units and 0.3259 respectively. Foreign firms are also found to export more as compared to domestic firms; the results show that the foreign owned firms export 0.5803 more units than domestic firms. This paper recommends that Kenyan firms should adopt internationally recognized certification standards in order for them to be more competitive in the international market and should embrace innovation by introducing new products and making improvements to their existing products; this can be achieved by investing more in research and development. These measures will increase firm export intensity leading to an overall increase in the country's volume of exports leading to an improved balance of trade, a significant factor to overall economic growth. This paper therefore provides valuable information on how Kenyan manufacturing firms can increase the proportion of revenue received from engaging in international trade.
\end{abstract}

Keywords: Export Intensity, Export Propensity, Firm Performance

\section{Introduction}

Economic growth is the increase in capacity of an economy to produce goods and services over a specified time period [22]. Economic growth is an important policy variable and countries strive to achieve a positive and sustainable economic growth by formulating and implementing different economic policies and strategies that best suit their respective economic characteristics and goals. A positive economic growth pattern achieved over a period of time is an indicator of economic progress. Economies in the pursuit of economic transformation have adopted various policies to achieve economic growth based on their resource endowments. One such economic policy is import substitution which encourages local manufacturing, increases export competitiveness with a view to reduce dependence on foreign imports. Export oriented policies is another policy adopted by various economies in Sub-Saharan Africa. This policy shift was motivated by the Economic success of East Asian countries dubbed the 'Asian Tigers'. This policy emphasizes on manufacturing with a view to sell in a foreign market, thereby by enabling domestic firms gain access to new markets in new territories and in the process expand their customer base, improve on production processes and achieve higher economies of scale leading to a growth in profits [9].

Kenyan manufacturing is made up of an informal sector and the formal sector. The formal sector consists of small, medium and large scale firms that adopt modern production processes and management techniques and employ more than five employees. The informal sector on the other hand engages in micro-scale production with limited technological investment in their production processes [1].

Kenya has adopted various policies with an aim to increase the volume of exports over the years, they include, Import substitution strategy (ISS), Structural Adjustment program (SAPs), introduction of the Export Promotion council and 
setting up of an Export Processing Zone, the Vision 2030 pillar on manufacturing and recently the Big Four Agenda (2018) which emphasize on manufacturing as one of the four key pillars to economic development. However, despite the various policies developed with the aim of boosting the volume and value of exports, Kenya's share in total global exports has remained low at $0.04 \%$ [36]. A comparison of imports and exports contribution to Gross Domestic Product (GDP) indicates that more imports have been flowing into the country as compared to exports. Imports account for $23.36 \%$ of GDP while exports account for $14.57 \%$ of GDP respectively implying a current account deficit. These economic imbalances will make it difficult for Kenya to achieve a high economic growth rate over a period of time [30].

For countries to achieve economic development, they should undertake structural changes in productivity that is from low to high level productivity, the manufacturing sector has been identified as a key sector through which its improvement can lead to economic development [33, 30], and [28]. In 2015 Kenya had the highest Unemployment rate in East Africa at $12.5 \%$, the urban youth unemployment rate stood at $25 \%$ and the rural rate at $9 \%$ [15]. Empirical evidence shows that the manufacturing sector has the highest employment multiplier. A study by [4] found that 100 jobs in the manufacturing sector supported 291 jobs in other sectors. These studies therefore highlight the importance of the manufacturing sector in the economy.

An intervention on the manufacturing sector creates backward and forward linkages and thereby creates job opportunities and bolsters entrepreneurship opportunities. A well founded manufacturing sector enhances economic development [16]. Kenyan Export to GDP ratio grew from $48 \%$ in 1996 to $64 \%$ in 2009 , however, this rate is still below Kenya's potential of $80 \%$ implying a low export performance [33]. Currently, the manufacturing sector contributes $9.2 \%$ to GDP, the government aims to raise this contribution to $15 \%$ in 2022, for this to be achieved sound policies and strategies need to be formulated [16].

Based on the above trade statistics Kenyan export performance has remained low despite various policies being adopted to boost export volumes (Import Substitution, Establishment of export promotion council, Export Processing zones, Vision 2030, Special Economic Zones Act). A study of firm level characteristics is important since it is at this level that key decisions are made, and the actual production of goods and services for the domestic and export market takes place [7]. These decisions affect the quality, quantity and the costs that a firm will incur to produce a unit of a good or service.

Previous studies on manufactured exports in Kenya have not been conclusive in explaining the determinants of export intensity in Kenya as they have majorly focused on the macro-economic factors at the expense of micro-economic factors [23-25]. By using the most recent World Bank Enterprise Survey data (2013) and a comprehensive methodology to analyze firm characteristics, this paper explains the factors that influence export behavior in Kenyan firms and offers policy recommendations.

\section{Literature Review}

This paper studies firm characteristics that determine a firm's export performance. Export performance takes on two dimensions; Export propensity and export intensity, the former refers to the decision to export or not, the latter refers to the ratio of exports to the total output by a firm. It is worth noting that these export dimensions are different and driven by heterogeneous factors to avoid confusion [19]. This study is motivated by Lawless and Whelan's, 2008 findings on the need to distinguish the export performance measures by studying export intensity and export propensity as independent determinants to export performance. A review of ninety micro-data studies on exports by [13] showed that about ten percent studied export intensity thereby showing that little research has been undertaken on export intensity.

\subsection{Innovation and Export Intensity}

Innovation is a key determinant to export intensity as it enhances a firm's technical efficiency leading to higher productivity in both quantity and quality. A crosssectional analysis studying the effect of innovation on export performance of Danish manufacturing firms by [18], sought to find the origin of innovation on whether it originated from customers, suppliers or universities. Export intensity the dependent variable, was measured by the share of exports in the firm's total sales, firm characteristics formed the explanatory variables matrix and included firm age, fixed assets and, investment in human capital captured by the firm's number of employees. The findings showed that customer preferences was the major driver of innovation to manufacturing firms implying that innovative activities by a firm appeals to customers and therefore promotes a firms export intensity and thus the inclusion of the innovation variable in this study to find out its effect on Kenyan Firms.

\subsection{Firm Ownership and Export Intensity}

Using survey data from a survey on Pakistani manufacturing firms [7], sought to find out the determinants of export intensity with specific emphasis on firm characteristics and supply side constraints. Their findings showed that firms with a foreign ownership exported more as compared to locally owned firms. This can be attributed to better technology employed by these firms into their production processes. Facilitation measures by the government like the setting up of export processing zone also impacted positively on export performance. Compliance to product and process certifications was found to add credibility to a firms products thereby a major determinant of export intensity. 


\subsection{Certification and Export Intensity}

Certification standards play a major role in international trade and for a good to be competitive in this market; it should meet various specifications in terms of quantity and quality [14]. This therefore explains the need for firms to have internationally recognized quality certifications an example is ISO 9000. A study by [21], examined the effect of certification on export performance in Pakistan. Logit model estimations were undertaken and the findings showed that ISO 9000 certification had a significant positive impact on export performance. This can be attributed to the fact that certification adds credibility to a good and thereby be competitive in the world market. The policy implication therefore is that firms should strive to upgrade output quality in order for them to penetrate more markets and be competitive. Certification variable is examined in this study and therefore its effect is established for Kenyan manufacturing firms.

\subsection{Firm Location and Export Intensity}

There exists a positive correlation between export intensity and geographical location of a firm, this observation is based on a study conducted on Sri Lankan manufacturing firms by [31]. This study focused specifically on manufacturing firms in clothing enterprises. The share of exports sales to total sales (export intensity) was the dependent variable and the explanatory variables included a dummy variable for ownership that is whether a firm is foreign owned or domestic, firm size, technological capacity given by the technological index, human capital, and geographical location. All the explanatory variables were found to be significant and therefore explained export intensity. This study showed that firms located near the capital were more likely to export; this behavior is explained by the positive locational externalities as well as good infrastructure implying lower transport costs.

\subsection{Export Intensity, Firm Size and Firm Age}

Studying the effects that accrue to firms as a result of them participating in international trade is important. Participation in international trade associated with positive externalities [34]. A study to find the link between employment patterns (quality of human capital) and export behavior on Kenyan manufacturing firms found that exporting firms were more productive than non-exporting firms [31]. Exporting firms utilize modern production technologies and import capital goods in order for them to remain competitive in the international markets. These firms therefore need a pool of skilled laborers to operate and sustain their production process. An economy should therefore strive to ensure that the quality of its labor force is able to match the market demand for skilled workers to achieve sustainable production. Firm age refers to the number of years a firm has been in operation [25]. The firm age variable is however ambiguous in literature as studies have given mixed results [7]. This can be explained by the fact that some new firms may be set up with a primary objective to export and on the other hand older firms gain market experience and build networks through which to market their products and penetrate new markets in foreign countries [20].

\section{Methodology}

This study adopted the Heckman approach [12], to estimate the determinants of export intensity in Kenyan manufacturing firms. We chose this method because it corrects for sample selection bias as exporting firms preselect themselves to export and possess some unique characteristics not present in non-exporting firms. The following series of equations how sample selection bias comes about and how the Heckman model corrects for it.

The Heckman model is a two-step model, the first stage models the probability of a firm participating in exporting. This is modeled as a Probit model of the form:

$$
\operatorname{probability}(E=1 \mid X i)=\varnothing(X i Y i)
$$

Where:

$E$ indicates whether a firm exports or not $(E=1$ if firm Exports, 0 otherwise)

$\mathrm{X}$ gives the explanatory variables

$\mathrm{Y}$ vector of exogenous parameters

$\phi$ is the cumulative distribution function of standard normal distribution; its estimation yields the results that can be used to predict the export intensity of each firm in the population.

It is important to note that the dependent variable (export propensity) should meet the exclusion restriction by having an indirect influence on export intensity in the second stage. The identification of a suitable exclusion restriction is however difficult as there's no specific method of identifying a valid restriction [1].

The inverse Mills ratio; given as the ratio of the probability distribution function and the cumulative distribution function, is computed in the first stage and is incorporated as an additional variable in the second stage in order to take care of possible sample selection bias. It is given as:

$$
\lambda_{i}=\frac{\phi(X i Y i)}{1-\phi(X i Y i)}
$$

$\Phi$ is the cumulative distribution function and $\lambda_{\mathrm{i}}$ gives the inverse mills ratio associated to a firm and is included as the additional independent variable in the second stage.

In the second stage, we correct for the pre-selection of firms by transforming the predicted individual probabilities as additional explanatory variables. The export intensity equation is specified as follows:

$$
\left.P^{*}=X i \beta+\mu\right)
$$

$\mathrm{P}$ is the underlying export intensity and is unobservable if a firm is a non-exporter and $\mathrm{X}$ gives the determinants of export intensity which in our case include Firm size, Firm location, Firm ownership, Innovation and certification. 
The conditional expectation for an exporting firm is therefore given as:

$$
E(P i \mid X i, P i=1)=X i \beta+E(\mu \mid X i, P i=1)
$$

We assume that the error terms are jointly normal, thus;

$$
E(P \mid X i, P i=1)=X i \beta+\rho \sigma_{\mu} \lambda(Z i \gamma)
$$

Where $\rho$ is the correlation between unobserved determinants of the decision to export and unobserved determinants of export intensity, $\sigma_{\mu}$ is the standard deviation of $\mu$ and $\lambda$ is the inverse mills ratio.

These sets of equations demonstrate Heckman's insight

Export Intensity $=\mathrm{f}($ Firm Ownership, Firm Location, Certification, Innovation, Firm Size, and Firm Age $)$

To model the interaction between export intensity and its determinants we estimate the following empirical model using the Ordinary Least squares technique and the Heckman approach to control for possible sample selection bias.

$$
\text { Exp }_{i}=B_{o}+B_{1} \text { Age }_{i}+B_{2} \text { Firm Ownership }+B_{3} \text { Certification }_{i}+B_{4} \text { Location }_{i}+B_{5} \text { Size }_{i}+B_{6} \text { Innovation }_{i}+
$$

\begin{tabular}{|c|c|c|}
\hline Variable & Definition and Measurement & Expected Sign \\
\hline Export Intensity & The dependent variable, Given by the ratio of exports over annual total sales of firm $i$ & \\
\hline Firm Age & The number of years the firm has been in operation since incorporation, 2013 minus year of incorporation. & Uncertain (+ or - ) \\
\hline Firm Ownership & A dummy variable that specifies a firm's ownership status, A firm with foreign ownership $=1$ otherwise $=0$ & Positive \\
\hline Certification & $\begin{array}{l}\text { Specifies whether the firm possesses an internationally recognized quality certification an example is ISO } \\
9000 \text {. If firm is Certified }=1 \text {, If not certified }=0\end{array}$ & Positive \\
\hline Location & $\begin{array}{l}\text { A categorical variable specifying a Firm's location as captured in the survey: Central }=0, \text { Nyanza }=1, N a k u r u=2 \text {, } \\
\text { Mombasa }=3 \text {, Nairobi }=4\end{array}$ & Uncertain (+ or - ) \\
\hline Innovation & $\begin{array}{l}\text { A dummy variable showing whether a firm launched a new product to the market or made a major } \\
\text { improvement (manufacturing process, distribution and packaging) to the existing products. New Product or } \\
\text { improvement }=1 \text {, No new products nor improvements }=0\end{array}$ & Positive \\
\hline
\end{tabular}

Table 1. Description of Variables.

\subsection{Source and Type of Data}

The study used the Kenya World Bank Enterprise Survey Data 2013 which collected data on various firm characteristics in Kenya some of which include: a firm's general information (Legal ownership structure, year of incorporation, location), Information on sales (Domestic sales and exports), the level of innovation in the firm and access to finance among other firm characteristics.

\section{Results and Discussion}

\subsection{Summary Statistics}

The table below gives a summary of the basic descriptive statistics: Number of observations, the mean, and standard deviation, the maximum and minimum values as well as

\begin{tabular}{|c|c|c|c|c|c|c|c|}
\hline Variable & Obs & Mean & Std. Dev. & Min & Max & Skewness & Kurtosis \\
\hline Exports intensity & 275 & 24.83 & 35.25 & 0 & 100 & 1.254431 & 3.089931 \\
\hline Firm age & 275 & 25.61 & 16.24 & 2 & 93 & 1.14124 & 4.799747 \\
\hline Certification & 275 & 0.305 & 0.461 & 0 & 1 & .8447485 & 1.7136 \\
\hline Region & 275 & 3.203 & 1.256511 & 1 & 5 & -.6093179 & 2.194218 \\
\hline Firm Size & 275 & 0.400 & 0.491 & 0 & 1 & .4082483 & 1.166667 \\
\hline Innovation & 275 & 0.713 & 0.453 & 0 & 1 & -.940252 & 1.884074 \\
\hline Firm Ownership & 275 & 0.222 & 0.416 & 0 & 1 & 1.33912 & 2.793243 \\
\hline
\end{tabular}
Kurtosis and Skewness.

Table 2. Variables Descriptive statistics.

Table 1 shows that firms analyzed on this study exported 24.83 percent of their output and had a mean age of 25.61 years with a standard deviation of 16.24 . The certification variable has a standard deviation of 0.461 and 30.5 per cent of the exporting firms had adopted an internationally recognized certification. 40 per cent of the exporting firms employed had more than 20 permanent employees. On firm innovation, 71.3 per cent of firms in this study introduced a new product or made substantial improvements to the existing set of products. Firm ownership that is whether a firm is domestically owned or foreign owned shows that 22 per cent of firms that participated in the study are foreign owned. 


\subsection{Regression Results}

Table 3 presents the regressions outputs that is OLS regression results and the Heckman regression results.

Table 3. Regression results.

\begin{tabular}{|c|c|c|}
\hline & OLS regression & Heckit regression output \\
\hline \multirow[t]{2}{*}{ Firm age } & -0.0448 & 0.000272 \\
\hline & $(-0.39)$ & $(1.45)$ \\
\hline \multirow[t]{2}{*}{ Certification } & $7.08^{* *}$ & $0.3259 * *$ \\
\hline & $(1.68)$ & $(1.72)$ \\
\hline \multicolumn{3}{|l|}{ Region } \\
\hline \multirow[t]{2}{*}{ Nyanza } & $-36.7434^{* * *}$ & $-0.97662 * * *$ \\
\hline & $(-4.98)$ & $(-2.75)$ \\
\hline \multirow[t]{2}{*}{ Mombasa } & $-15.3836^{* *}$ & 0.0919 \\
\hline & $(-2.50)$ & $(0.33)$ \\
\hline \multirow[t]{2}{*}{ Nairobi } & $-35.814^{* * *}$ & -0.1262 \\
\hline & $(-6.85)$ & $(-0.54)$ \\
\hline \multirow[t]{2}{*}{ Nakuru } & $-33.6338^{* * *}$ & $-0.7986 * *$ \\
\hline & $(-4.55)$ & $(-2.26)$ \\
\hline \multicolumn{3}{|l|}{ Firm Size } \\
\hline \multirow[t]{2}{*}{ Medium Firm } & 17.223 & 0.596 \\
\hline & $(1.96)$ & $(1.40)$ \\
\hline \multirow[t]{2}{*}{ Large Firm } & $14.970 * *$ & $0.825 * *$ \\
\hline & $(2.42)$ & $(2.72)$ \\
\hline \multirow[t]{2}{*}{ Mega Firm } & $49.409 * * *$ & 1.10 \\
\hline & $(3.59)$ & $(1.7)$ \\
\hline \multirow[t]{2}{*}{ Innovation } & $9.1385^{*}$ & $0.4747 * * *$ \\
\hline & $(2.26)$ & $(2.60)$ \\
\hline \multirow[t]{2}{*}{ Firm Ownership } & $16.4189^{* * *}$ & $0.5803 * * *$ \\
\hline & $(3.54)$ & $(2.69)$ \\
\hline \multirow[t]{2}{*}{ Constant } & $36.71^{* * *}$ & $-0.6509 * * *$ \\
\hline & $(5.99)$ & $(2.37)$ \\
\hline Observations & 275 & 275 \\
\hline$R^{2}$ & 0.3046 & Mills Ratio $=-0.884(0.15)$ \\
\hline $\operatorname{Adj} R^{2}$ & 0.2755 & \\
\hline
\end{tabular}

Source: Research data

Notes:

i Central region is the reference category for the region variable.

ii Small firm is the reference category for firm size variable.

iii t-statistic in parentheses.

iv Significant at $*, * *, * * *$ the 10 per cent, 5 per cent and 1 per cent respectively.

These two regressions are undertaken for comparison purposes, we interpret the Heckman output as it takes care of sample selection bias, as firms that export preselect themselves to enter the export market and possess unique firm characteristics that enable them to export.

Possession of an internationally recognized certification by a firm is positive and significant at five per cent. We take a firm that has adopted a certification standard as the reference and we find that this firm exports 0.3259 units more than a firm that has not adopted a certification standard. Similar results were obtained on Pakistani manufacturing firms by [21]. Adoption of a certification standard enhances the credibility of a firm's products in the international market. The international market being competitive means that quality is a major determinant to products marketability, certification standards therefore act as a benchmark through which the quality of a product can be determined.

In this study, manufacturing firms are geographically located into five regions that is: Central, Nyanza, Mombasa,
Nairobi, and Nakuru regions. We take central region as the reference category and the regression results show that a firm in Nyanza will export 0.97662 units less than a firm in the Central region, similarly firms in Nairobi and Nakuru will export fewer units of goods as compared to firms in the Central region by 0.1262 and 0.7986 units respectively. However a firm in Mombasa will export 0.0919 more units than a firm in the central region, this is partially explained by the fact that Mombasa is located along the coast and the firms in this region therefore incur less expense to transport their goods to the port to be exported. These regression results clearly show that the further a firm is away from the port of Mombasa the less amount of goods they export as Nyanza has the highest negative coefficient at 0.97662 followed by Nakuru at 0.7986 and finally Nairobi at 0.1262 . Similar results were obtained by [7] for Pakistani manufacturing firms and showed that firms located near a port or a major transport route were more likely to export more as compared to firms located further away from the port.

Firm size measured by the number of employees in a firm is modeled as a categorical variable. In this study a small firm is made up of 1-49 employees, medium firm has 50-99 employees, large firm has 100-499 employees and mega firm has 500 employees and above. Small firm is taken as the reference variable and we find that large firms are the most export intensive and export 0.825 more units as compared to a small firm. This implies that large firms are more efficient and therefore are can export a larger proportion of their output. A study of manufacturing firms in New Zealand found that larger firms export more as compared to smaller firms [6].

Innovation measured by whether a firm has introduced a new product or made significant changes to an existing product within the last three years is positive and significant at one per cent. The results show that a firm that has introduced a new product or made significant changes to an existing product export more by 0.4747 units as compared to a firm that has not introduced or made a significant change to its products. This is similar to results obtained by [18] on Danish manufacturing firms which showed that innovation has a positive relationship with export intensity. Innovative firm are more appealing to customers leading to an increased demand for its goods as innovation is accompanied by improvements in quality and quantity thus enabling a product to compete more favorably in the international market.

The mills ratio which corrects for selection bias is a ratio of the probability distribution function and the cumulative distribution function has a coefficient of -0.884 and is insignificant at five percent level of significance implying that sample selection bias does not pose a major problem in this study. This ratio is calculated from the first stage of the Heckman estimation and is included as an explanatory variable in the second stage estimation of the Heckman regression to correct for sample selection bias arising from the pre-selection of firms into participating in export trade.

The firm ownership variable is positive and significant at one percent. We classify a firm based on its ownership status 
that is whether it is a domestic firm or a foreign firm. In this study a firm is foreign owned if a foreigner has a share in its firm ownership structure. The regression results show that a foreign owned firm exports 0.5803 units more as compared to a domestic firm. Similar results were obtained by $[3,31]$, implying that foreign firms' export intensity is much higher as compared to domestic firms. This is attributed to the experience gained by foreign firms in the international trade. These firms also have a wider market presence in other markets making them penetrate new markets much easily as compared to domestic firms.

\section{Conclusion}

This study examined the determinants of export intensity among Kenyan manufacturing firms by studying the interaction between specific firm characteristics and its effect on export intensity using World Bank Enterprises Survey data for the year 2013. The paper adopted ordinary least squares and Heckman estimation method to estimate the econometric model. The results of the two estimation techniques show similar signs except for the Firm age, Mombasa Region, and constant. However, the magnitude of the coefficients differed with OLS coefficients being much larger than the Heckman regression output. This study adopts the Heckman regression output as it corrects for sample selectivity bias and endogeneity issues as exporting firms preselect themselves to export. A total of 275 firms were used to analyze the study objectives. The key findings of the study are that certification and innovation have a positive and statistically significant effect on export intensity among manufacturing firms in Kenya. Furthermore, the paper provided evidence that a firm's proximity to the port has a significant effect on the volume of exports. For instance, it was found that Nyanza and Nakuru region had exported 0.9766 and 0.7986 less units as compared to central province which is much closer to ports of exit that is Nairobi and Mombasa. Intuitively it means that the farther the firm from the port the lower the export intensity.

The results provide evidence that large firms tend to export more of their output as its relationship with export intensity is positive and statistically significant. This is in line with economic theory as the higher the number of permanent and skilled workers in a firm, the higher the economies of scale hence an increase in export intensity this is attributed to increased efficiency by the skilled workers. The findings also provide evidence that firm age has an impact on a firm's export intensity. For this study, exporting firms have an average age of 25 years and a positive relationship exists between firm age and export intensity. However, it is worth noting that in literature, firm age is ambiguous, as firm's may be set up with a primary objective to export by targeting specific market niches and employing new management and production techniques.

We conclude this paper by offering the following policy implications. There's need to improve on the country's transport network, this is shown by the fact that export intensities of firms located farther away from the port were lower as compared to ones with a close proximity to ports. An improvement of the Country's transport network would lower logistical costs incurred by firms for their goods to reach exit points, this will enable these firms to retain more of their earnings thereby use it to improve other production processes. Secondly, there's need for Kenyan firms to adopt internationally recognized certification standards in order for their products to be competitive in the international market as certification adds credibility to a product. Certification also enables goods to enter some markets like European Union, as they require compliance with specified certification standards. Finally there's need for Kenyan firms invest in coming up with new or make improvements to the existing products. This can be achieved through research and development, there's need therefore for firms to make resource allocations for research and development. The government can also offer subsidies to promote research and development. Innovation is a key determinant to export intensity as it unlocks new market niches and creates new product lines or expand existing ones.

\section{References}

[1] Abala, D. O. (2013). Export propensity and intensity of Kenyan manufacturing firms: An empirical analysis. Journal of Emerging Issues in Economics, Finance and Banking (JEIEFB), 2(2), 638-654.

[2] Bernard, A. B., \& Jensen, J. B. (2004). Why some firms export. Review of economics and Statistics, 86(2), 561-569.

[3] Bhavani, T. A., \& Tendulkar, S. D. (2001). Determinants of firm-level export performance: a case study of Indian textile garments and apparel industry. Journal of International Trade \& Economic Development, 10(1), 65-92.

[4] Bivens, J. (2003). Updated Employment multipliers for the US Economy (2003). Economic Policy Institute. Washington DC.

[5] Castellani, D. (2002). Export behavior and productivity growth: Evidence from Italian manufacturing firms. Weltwirtschaftliches Archiv, 138(4), 605-628.

[6] Chetty, S. K., \& Hamilton, R. T. (1993). Firm-level determinants of export performance: a meta-analysis. International Marketing Review, 10(3).

[7] Din, M., Ghani, E., \& Mahmood, T. (2009). Determinants of export performance of Pakistan: evidence from the firm-level data. The Pakistan Development Review, 227-240.

[8] Farinas, J. C., \& Martín - Marcos, A. (2007). Exporting and economic performance: firm-level evidence of Spanish manufacturing. World Economy, 30(4), 618-646.

[9] Fonchamnyo, D. C. (2014). Determinants of export propensity and intensity of manufacturing firms in Cameroon: an empirical assessment. Applied Economics and Finance, 1(2), 30-36.

[10] Giles, J., \& Williams, C. L. (2000). Export-led growth: a survey of the empirical literature and some non-causality results. Part 1. The Journal of International Trade \& Economic Development, 9(3), 261-337. 
[11] Heckman, J. J. (1976). The common structure of statistical models of truncation, sample selection and limited dependent variables and a simple estimator for such models. In Annals of Economic and Social Measurement, Volume 5, number 4 (pp. 475-492).

[12] Heckman, J. J. (1979), "Sample Selection as a Specification Error," Econometrica, 47, 153-161.

[13] Hiep, N., \& Nishijima, S. (2009). Export intensity and impacts from firm characteristics, domestic competition and domestic constraints in Vietnam: A micro-data analysis (No. 238).

[14] Iyer, K. (2010). The Determinants of Firm-Level Export Intensity in New Zealand Agriculture and Forestry1, 2. Economic analysis and Policy, 40(1), 75-86.

[15] KIPPRA. (2017). Kenya Economic Report 2017. Nairobi: KIPPRA.

[16] Kenya Association of Manufacturers. (2018). Manufacturing Priority Agenda, 2018. Nairobi: kenya Association of Manufacturers.

[17] Kenya National Bureau of Statistics. (2017). Economic Survey 2017. Nairobi: Government Printer.

[18] Laursen, K. (2008). The effect of knowledge sources for export performance in manufacturing and services: Danish firm-level evidence. Copenhagen Business School.

[19] Lawless, M., \& Whelan, K. (2008). Where do firms export, how much, and why? (No. 08/21). Working Paper Series.

[20] Lucas, S. (2017). The impact of demographic and social factors on firm performance in Kenya. Journal of Business and Economic Development, 2(4), 255-261.

[21] Masakure, O., Henson, S., \& Cranfield, J. (2009). Standards and export performance in developing countries: Evidence from Pakistan. The Journal of International Trade \& Economic Development, 18(3), 395-419.

[22] Medina-Smith, E. J., \& CNUCED. (2001). Is the export-led growth hypothesis valid for developing countries? A case study of Costa Rica. CNUCED: UN.

[23] Mohan, R., \& Nandwa, B. (2007). Testing Export-led Growth Hypothesis in Kenya: an ADRL bounds test approach.

[24] Muhoro, G., \& Otieno, M. (2014). Export led growth hypothesis: Evidence from Kenya. Journal of World Economic Research, 3(4), 37-46.

[25] Ngumi, M. P. (2009). Exports and economic growth: the case for Kenya. MA Research paper, University of Nairobi. Watson. PL (2001). "Export Processing zones", Africa region working paper series, (17).

[26] Osunsan, O. K., Nowak, J., Mabonga, E., Pule, S., Kibirige, A. R., \& Baliruno, J. B. (2015). Firm age and performance in Kampala, Uganda: A selection of small business enterprises. International Journal of Academic Research in Business and Social Sciences, 5(4), 364-374.

[27] Roberts, M. J., \& Tybout, J. R. (1997). The decision to export in Colombia: an empirical model of entry with sunk costs. The American Economic Review, 545-564.

[28] Rodrik, D. (2007). The real exchange rate and economic growth: theory and evidence. Harvard University.

[29] UNCTAD. (2016). General Profile: Kenya. Available at http://unctadstat.unctad.org/CountryProfile/GeneralProfile/enGB/404/index.html

[30] Vision 2030 (2007). A globally competitive and prosperous Kenya. Government Printers.

[31] Wignaraja, G. (2008). Foreign ownership, technological capabilities and clothing exports in Sri Lanka. Journal of Asian Economics, 19(1), 29-39.

[32] Were, M., \& KIPPRA, K. (2006, December). ExportOrientation and Employment Patterns in Kenya's Manufacturing Sector: Firm-Level Evidence. In Draft for presentation at the CSAE conference.

[33] World Bank. ( 2012). Kenya Exports Performance Overview. Washington D. C: The World Bank.

[34] World Bank. (1993). The East Asian Miracle. Oxford University Press. Washington D. C.

[35] WTO. (2016). Kenya Merchandise Trade.

[36] http://stat.wto.org/CountryProfile/WSDBCountryPFView.aspx? Country=KE\&Language

[37] Yoshino, Y. (2008). Domestic constraints, firm characteristics, and geographical diversification of firm-level manufacturing exports in Africa. The World Bank. 